\title{
Pengaruh Polyurethan pada Kemampuan Meredam Suara Home Made Foam
}

\author{
Riki Perdana*, Tri Utami, Erlin Eveline, Devi Afriani, dan Suparno \\ Program Pascasarjana, Pendidikan Fisika Universitas Negeri Yogyakarta, D.I Yogyakarta 55281
}

Intisari

\begin{abstract}
Telah dihasilkan komposisi busa yang efektif sebagai bahan peredam suara berdasarkan nilai koefisien absorbsi suara. Metode yang dilakukan adalah eksperimen, dengan mencampurkan bahan utama (polyurethan) dan bahan pengembang (isocyanate). Terdapat lima variasi penelitian, dengan cairan pengembang sebagai variabel kontrol. Adapun hasil yang diperoleh dari variasi pertama hingga kelima berturut-turut adalah 0,$152 ; 0,072 ; 0,042$; 0,028 dan 0,056. Dari hasil temuan berupa busa bahan poliurethan dapat disimpulkan bahwa semakin sedikit polyurethan yang ditambahkan semakin besar nilai koefisien absorbsi sehingga kemampuan meredam suara busa menjadi lebih baik.
\end{abstract}

\begin{abstract}
Effective foam composition has been produced as sound absorbing material based on sound absorption coefficient value. The method used is experimentation, by mixing the main ingredients (polyurethane) with the developer liquid (isocyanate). There are five variations of research, with the isocyanate as a control variable. The results obtained from the first to fifth variations in a row are $0.152 ; 0.072 ; 0.042 ; 0.028$ and 0.056 . From the findings it can be concluded that the less polyurethane is added the greater the absorption coefficient value so it is better to absorbs the sound.
\end{abstract}

Keywords: Polyurethan; coefficient of sound absorption.

*Corresponding author: rikifisika95@gmail.com

http://dx.doi.org/10.12962/j24604682.v15i2.4315

2460-4682 @Departemen Fisika, FSains-ITS

\section{PENDAHULUAN}

Saat ini kebutuhan ruang kedap suara terus meningkat. Didunia musik, ruang kedap suara dapat mengurangi resiko kerusakan sistem pendengaran [1]. Ruang kedap suara juga dapat menambah kualitas musik karena terhindar dari gemadan dengung [2]. Selain dunia musik, ruang kedap suara juga dibutuhkan dalam penelitian untuk memperoleh hasil yang maksimal. Oleh sebab itu penelitian mengenai bahan yang efektif sebagai peredam suara masih harus terus ditingkatkan.

Penelitian sebelumnya telah menemukan berbagai bahan yang efektif sebagai peredam suara. Bahan yang sering digunakan adalah glass wool dan rockwool [3]. Glass wool merupakan bahan yang terbuat dari serat fiber yang diproses sedemikan rupa sehingga mirip dengan tekstur bulu domba [4]. Rock wool merupakan bahan seperti wol yang dibuat dari batu vulkanis dan batu gamping yang dipanaskan [5]. Meskipun efektif sebagai bahan peredam suara, harga glass wool dan rock wool sangat mahal.

Penelitian lain menemukan bahan yang lebih murah dan efektif sebagai peredam suara. Bahan tersebut berupa bahan organik dari serabut kelapa [6], limbah batang kelapa sawit [7], dan serat daun nanas [8]. Namun, penggunaan bahan or- ganik berpotensi menimbulkan jamur dan bakteri sehingga dapat mengurangi kualitas bahan. Untuk memenuhi kebutuhan peredam suara, diperlukan bahan yang efektif, murah, dan tidak mudah rusak.

Salah satu bahan yang dapat digunakan untuk memenuhi kebutuhan peredam suara adalah busa polyurethan. Meskipun tersusun dari bahan kimia, harga busa polyurethan sangat terjangkau. Polyurethan adalah suatu bahan hasil polimerisasi urethan. Dalam zat ini terkandung komponen nitrogen, karbon, dan oksigen dengan gugus (-NH-CO-O). Busa polyurethan terdiri bahan kimia komponen A (polyol) dan komponen B (isocyanate) sebagai pengembang. Campuran kedua bahan ini menghasilkan busa dengan karakteristik yang bervariasi tergantung komposisi yang digunakan. Busa polyurethan [9] dapat menjadi bahan peredam suara yang baik karena memiliki jumlah pori-pori yang sangat banyak dan tersebar merata [10].

Dalam penelitian ini, dilakukan variasi komposisi larutan polyurethan dan isocyanate untuk memperoleh koefisien absorbsi tertinggi. Setiap variasi bahan diuji dengan tabung resonansi yang dihubungkan dengan frekuensi tertentu. Bahan dengan koefisien absorbsi tertinggi menunjukkan komposisi yang paling efektif sebagai peredam suara dengan bahan dasar polyurethan. 


\section{METODOLOGI}

Penelitian ini menggunakan metode eksperimen, dengan mencampurkan bahan utama polyurethan (komponen A) dan isocyanate (komponen B). Setelah itu, dilakukan pengukuran intensitas bunyi untuk menentukan nilai koefisien absorbsi busa. Dibuat lima sampel dengan perbandingan bahan pengembang dan polyurethan masing-masing 1:1, 1:2, 1:3,1:4, dan 1:5.

Penelitian dilakukan dalam dua tahapan, yaitu pembuatan busa dan pengukuran nilai intensitas bunyi. Busa dibuat dengan mencampurkan polyurethan sebagai variabel bebas dan larutan isocyanate sebagai variabel kontrol. Adapun metodologi pembuatan busa adalah sebagai berikut.

\section{Alat dan bahan}

Alat dan bahan yang digunakan adalah komponen A: $200 \mathrm{ml}$, komponen B: $200 \mathrm{ml}$, timbangan Digital: 1 buah, gelas kimia $100 \mathrm{ml}$ : 2 buah, batang pengaduk: 1 buah, wadah penyimpanan busa (Dalam penelitian ini menggunakan tutup pipa (2 inci)): 10 buah, sound level meter: 1 buah, audio frekuensi generator: 1 buah.

\section{Langkah pembuatan busa polyurethan}

Dalam pembuatan busa ini, peneliti mengikuti petunjuk/arahan yang terdapat dalam pedoman pembelian busa polyurethan. Namun, dilakukan modifikasi mengenai ukuran bahan sehingga dihasilkan beberapa buah busa dengan komponen tertentu. Berikut langkah pembuatan busa yang dilakukan.

1. Komponen A (pengembang) sebagai variabel kontrol dan komponen B (polyurethan) sebagai variable bebas. Menyiapkan komponen A sebanyak lima sampel, masing-masing $2 \mathrm{ml}$ kemudian menyiapkan komponen B sebanyak lima sampel pula, masing-masing dengan ukuran $2 \mathrm{ml}, 4 \mathrm{ml}, 6 \mathrm{ml}, 8 \mathrm{ml}$ dan $10 \mathrm{ml}$. Agar dihasilkan perbandingan massa 1:1, 1:2, 1:3, 1:4, dan 1:5. Menuangkan komponen A dalam suatu wadah yang digunakan sebagai wadah busa, setelah itu, campurkan dengan komponen B dan diaduk hingga merata. Tunggu sekitar 30-60 sekon hingga terbentuk busa sempurna dan tidak terjadi lagi proses pengembangan.

2. Komponen B (polyurethan) sebagai variabel kontrol dan komponen A (pengembang) sebagai variable bebas.

Menyiapkan komponen B sebanyak lima sampel, masing-masing $2 \mathrm{ml}$ kemudian menyiapkan komponen A sebanyak lima sampel pula, masing-masing dengan ukuran $2 \mathrm{ml}, 4 \mathrm{ml}, 6 \mathrm{ml}, 8 \mathrm{ml}$ dan $10 \mathrm{ml}$. Agar dihasilkan perbandingan massa 1:1, 2:1, 3:1, 4:1, dan 5:1. Tuangkan komponen A dalam suatu wadah yang digunakan sebagai wadah busa. Setelah itu, campurkan dengan komponen $\mathrm{B}$ dan diaduk hingga merata. Tunggu sekitar 30-60 sekon hingga terbentuk busa sempurna dan tidak terjadi lagi proses pengembangan.

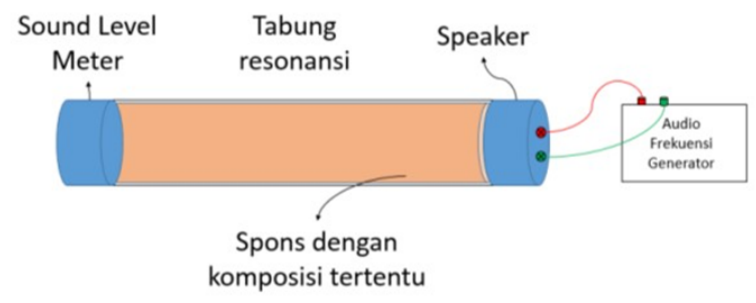

Gambar 1: Instrumen untuk mengukur nilai koefisien absorbsi bunyi.

\section{Merancang alat ukur}

Alat ukur yang dirancang menggunakan pipa pvc 2 inch dengan panjang $15 \mathrm{~cm}$. Kedua bagian pipa (kiri dan kanan) ditutup dengan penutup pipa yang telah dilubangi. Bagian kiri dilubangi untuk meletakkan sound level meter agar dapat mengukur taraf intensitas bunyi setiap komponen. Bagian kanan dilubangi untuk meletakkan speaker sebagai sumber frekuensi. Nilai intensitas bunyi diukur dengan menggunakan alat yang telah dirancang, seperti pada Gambar 1. Pengukuran bertujuan melihat efektivitas penyerapan suara oleh setiap busa.

\section{Teknik analisis data}

Teknik pengukuran dilakukan dengan memasukkan busa ke dalam instrument ukur. Kemudian instrumen diberi bunyi dengan lima frekuensi yang berbeda yaitu 500, 600, 700, 800, dan $900 \mathrm{~Hz}$. Pengukuran dilakukan sebanyak 10 kali pengulangan. Dari hasil penelitian ditemukan nilai taraf intensitas bunyi yang berbeda untuk setiap frekuensi. Taraf intensitas bunyi ini digunakan untuk menentukan besar koefisien absorbsi setiap bahan.

Data taraf intensitas bunyi kemudian dicatat dan dibandingkan (sebelum dan sesudah diberi busa) untuk menghitung nilai koefisien absorbsi bunyi. Perhitunghan nilai koefisien absorbsi bunyi dapat menggunakan persamaan:

$$
T I=T I_{\circ} e^{\alpha x}
$$

dengan $\mathrm{TI}=$ taraf intensitas akhir $(\mathrm{dB}), \mathrm{TI}_{\circ}=$ taraf intensitas awal $(\mathrm{dB}), \alpha=$ koefisien absorbsi bunyi, $\mathrm{x}=$ tebal bahan $(\mathrm{cm})$.

Taraf intensitas awal yang dimaksud adalah taraf intensitas bunyi saat pipa dalam keadaan kosong (belum dimasukkan busa). Taraf intensitas akhir adalah hasil pengukuran taraf intensitas bunyi setelah dimasukkan busa ke dalam pipa. Tebal bahan yang dimaksud adalah tebal busa hasil dari pembuatan busa setelah mencampurkan komponen A dan B dengan perbandingan tertentu. Setelah dicampurkan diketahui bahwa jika komponen A (pengembang) yang digunakan terlalu banyak, tidak terbentuk busa. Busa yang dapat diukur hanya pada perbandingan komponen A (pengembang) dan komponen B (polyurethan) masing-masing 1:1, 1:2, 1:3, 1:4, dan 1:5.

Data hasil perhitungan dianalisis untuk menentukan komposisi busa yang efektif sebagai bahan peredam suara. 
TABEL I: Nilai taraf intensitas (TI) bunyi sebelum dan sesudah diberi busa dengan perbandingan 1:1.

\begin{tabular}{|c|c|c|c|c|c|c|c|c|c|c|}
\hline \multirow[t]{2}{*}{ No } & \multicolumn{2}{|c|}{$500 \mathrm{~Hz}$} & \multicolumn{2}{|c|}{$600 \mathrm{~Hz}$} & \multicolumn{2}{|c|}{$700 \mathrm{~Hz}$} & \multicolumn{2}{|c|}{$800 \mathrm{~Hz}$} & \multicolumn{2}{|c|}{$900 \mathrm{~Hz}$} \\
\hline & $\begin{array}{c}\text { TI Awal } \\
(\mathrm{dB})\end{array}$ & $\begin{array}{l}\text { TI Akhir } \\
(\mathrm{dB})\end{array}$ & $\begin{array}{c}\text { TI Awal } \\
(\mathrm{dB})\end{array}$ & $\begin{array}{l}\text { TI Akhir } \\
\text { (dB) }\end{array}$ & $\begin{array}{l}\text { TI Awal } \\
\text { (dB) }\end{array}$ & $\begin{array}{l}\text { TI Akhir } \\
\text { (dB) }\end{array}$ & $\begin{array}{c}\text { TI Awal } \\
\text { (dB) }\end{array}$ & $\begin{array}{l}\text { TI Akhir } \\
(\mathrm{dB})\end{array}$ & $\begin{array}{c}\text { TI Awal } \\
\text { (dB) }\end{array}$ & $\begin{array}{l}\text { TI Akhir } \\
\text { (dB) }\end{array}$ \\
\hline 1 & 95 & 76,5 & 102,8 & 83,6 & 103,6 & 77,8 & 99,2 & 73,7 & 99,5 & 73,1 \\
\hline 2 & 95,5 & 76,6 & 102,7 & 83,8 & 103,5 & 77,9 & 99,1 & 73,1 & 99,6 & 73 \\
\hline 3 & 95,4 & 76,7 & 102,3 & 83,7 & 103,4 & 78 & 99 & 73,1 & 99,7 & 73,2 \\
\hline 4 & 97 & 76,8 & 101,6 & 83,6 & 103,3 & 79 & 97,7 & 73,1 & 99,8 & 73,3 \\
\hline 5 & 101,7 & 76,9 & 101,5 & 83,5 & 103,2 & 78 & 97,6 & 73 & 99,9 & 73,2 \\
\hline 6 & 98 & 76,8 & 101,4 & 83,4 & 103,1 & 78 & 97,7 & 72,9 & 100 & 73 \\
\hline 7 & 94,7 & 77 & 101,3 & 83,5 & 103,2 & 78,1 & 97,8 & 72,9 & 100,1 & 72,9 \\
\hline 8 & 92,6 & 77,1 & 101,1 & 83,7 & 103,4 & 78,1 & 97,6 & 72,9 & 100 & 73 \\
\hline 9 & 93,3 & 77,2 & 101,2 & 83,9 & 103,3 & 78,1 & 98,8 & 72,9 & 99,9 & 72,9 \\
\hline 10 & 93,2 & 77,3 & 102,5 & 83,8 & 103,4 & 78 & 98,8 & 73,2 & 100,1 & 72,8 \\
\hline Rata-rata & 95,64 & 76,89 & 101,84 & 83,65 & 103,34 & 78,1 & 98,33 & 73,08 & 99,86 & 73,04 \\
\hline Koefisien & & 0,13 & & 0,12 & & 0,16 & & 0,17 & & 0,18 \\
\hline SD & & & & & 0,026 & & & & & \\
\hline
\end{tabular}

Keefektifan bahan ditentukan berdasarkan nilai koefisien absorbsi. Nilai koefisien absorbsi bervariasi dari 0 hingga 1. Semakin besar nilai koefisien absorbsi, semakin baik bahan digunakan sebagai peredam suara.

\section{HASIL DAN DISKUSI}

\section{Hasil pengamatan}

Pengukuran dilakuan dengan menghitung nilai taraf intensitas bunyi sebelum dan sesudah diberi busa. Berdasarkan pengukuran, nilai taraf intensitas bunyi berbeda untuk setiap bahan pada frekuensi 500-900 Hz. Hasil dari pengukuran untuk perbandingan 1:1 komponen A (pengembang) dan komponen B (polyurethan) dapat dilihat pada Tabel I.

Pada percobaan pertama, saat perbandingan 1:1 terlihat bahwa ketika diberi frekuensi sebesar $500 \mathrm{~Hz}$ rata-rata taraf intensitas bunyi awal adalah sebesar 95,64 dB dan ketika ditambahkan busa yang dibuat, taraf intensitas bunyi turun sebesar 18,75 dB. Dengan menggunakan Persamaan (1) diperoleh koefisien absorbsi bunyi sebesar 0.13. Pada saat diberi sumber frekuensi 600, 700, 800 dan $900 \mathrm{~Hz}$ diperoleh selisih taraf intensitas bunyi sebelum dan sesudah masing-masing sebesar 18,19 dB, 25,24 dB, 25,25 dB dan 26,82 dB. Sehingga diperoleh nilai koefisien absorbs bunyi pada frekuensi tersebut masing-masing sebesar 0,$12 ; 0,16 ; 0,17$; dan 0,18 . Dengan demikian pada perbandingan 1:1 diperoleh rata-rata sebesar 0,152 dengan nilai standar deviasi sebesar 0,26. Data percobaan 1:2 dapat dilihat pada Tabel II.

Pada percobaan kedua, saat perbandingan 1:2 terlihat bahwa ketika diberi frekuensi sebesar $500 \mathrm{~Hz}$ rata-rata taraf intensitas bunyi awal adalah sebesar 95,64 dB dan ketika ditambahkan busa yang dibuat, taraf intensitas bunyi turun sebesar 25,02 dB. Dengan menggunakan Persamaan (1) diperoleh koefisien absorbsi bunyi sebesar 0,09. Pada saat diberi sumber frekuensi 600, 700, 800 dan $900 \mathrm{~Hz}$ diperoleh selisih taraf intensitas bunyi sebelum dan sesudah masing-masing sebesar
24,54 dB, 15,38 dB, 14,76 dB dan 26,22 dB. Sehingga diperoleh nilai koefisien absorbsi bunyi pada frekuensi tersebut masing-masing sebesar 0,08; 0,05; 0,05; dan 0,09. Dengan demikian pada perbandingan 1:2 diperoleh rata-rata sebesar 0,072 dengan nilai standar deviasi sebesar 0,0205. Data percobaan 1:3 dapat dilihat pada Tabel III.

Pada percobaan ketiga, saat perbandingan 1:3 terlihat bahwa ketika diberi frekuensi sebesar $500 \mathrm{~Hz}$ rata-rata taraf intensitas bunyi awal adalah sebesar 95,64 dB dan ketika ditambahkan busa yang dibuat, taraf intensitas bunyi turun sebesar 12,34 dB. Dengan menggunakan persamaan (1) diperoleh koefisien absorbsi bunyi sebesar 0.04. Pada saat diberi sumber frekuensi 600, 700, 800 dan $900 \mathrm{~Hz}$ diperoleh selisih taraf intensitas bunyi sebelum dan sesudah masing-masing sebesar $13,77 \mathrm{~dB}, 14,8 \mathrm{~dB}, 17,1 \mathrm{~dB}$ dan 14,19 dB. Sehingga diperoleh nilai koefisien absorbsi bunyi pada frekuensi tersebut masingmasing sebesar 0,04; 0,04; 0,05; dan 0,04. Dengan demikian pada perbandingan 1:3 diperoleh rata-rata sebesar 0,042 dengan nilai standar deviasi sebesar 0,004. Data percobaan 1:4 dapat dilihat pada Tabel IV.

Pada percobaan keempat, saat perbandingan 1:4 terlihat bahwa ketika diberi frekuensi sebesar $500 \mathrm{~Hz}$ rata-rata taraf intensitas bunyi awal adalah sebesar 95,64 dB dan ketika ditambahkan busa yang dibuat, taraf intensitas bunyi turun sebesar 2,33 dB. Dengan menggunakan Persamaan (1) diperoleh koefisien absorbsi bunyi sebesar 0,01. Pada saat diberi sumber frekuensi 600, 700, 800 dan $900 \mathrm{~Hz}$ diperoleh selisih taraf intensitas bunyi sebelum dan sesudah masing-masing sebesar $3,59 \mathrm{~dB}, 9,88 \mathrm{~dB}, 12,86 \mathrm{~dB}$ dan 17,89 dB. Sehingga diperoleh nilai koefisien absorbsi bunyi pada frekuensi tersebut masingmasing sebesar 0,01; 0,03; 0,04; dan 0,05. Dengan demikian pada perbandingan 1:4 diperoleh rata-rata sebesar 0,028 dengan nilai standar deviasi sebesar 0,018. Data percobaan 1:5 dapat dilihat pada Tabel V.

Pada percobaan kelima, saat perbandingan 1:5 terlihat bahwa ketika diberi frekuensi sebesar $500 \mathrm{~Hz}$ rata-rata taraf intensitas bunyi awal adalah sebesar 95,64 dB dan ketika ditambahkan busa yang dibuat, taraf intensitas bunyi turun sebe- 
TABEL II: Nilai taraf intensitas (TI) bunyi sebelum dan sesudah diberi busa dengan perbandingan 1:2.

\begin{tabular}{|c|c|c|c|c|c|c|c|c|c|c|}
\hline \multirow[t]{2}{*}{ No } & \multicolumn{2}{|c|}{$500 \mathrm{~Hz}$} & \multicolumn{2}{|c|}{$600 \mathrm{~Hz}$} & \multicolumn{2}{|c|}{$700 \mathrm{~Hz}$} & \multicolumn{2}{|c|}{$800 \mathrm{~Hz}$} & \multicolumn{2}{|c|}{$900 \mathrm{~Hz}$} \\
\hline & $\begin{array}{c}\text { TI Awal } \\
\text { (dB) }\end{array}$ & $\begin{array}{l}\text { TI Akhir } \\
\text { (dB) }\end{array}$ & $\begin{array}{c}\text { TI Awal } \\
\text { (dB) }\end{array}$ & $\begin{array}{l}\text { TI Akhir } \\
\text { (dB) }\end{array}$ & $\begin{array}{c}\text { TI Awal } \\
\text { (dB) }\end{array}$ & $\begin{array}{l}\text { TI Akhir } \\
\text { (dB) }\end{array}$ & $\begin{array}{l}\text { TI Awal } \\
\text { (dB) }\end{array}$ & $\begin{array}{l}\text { TI Akhir } \\
\text { (dB) }\end{array}$ & $\begin{array}{c}\text { TI Awal } \\
\text { (dB) }\end{array}$ & $\begin{array}{l}\text { TI Akhir } \\
\text { (dB) }\end{array}$ \\
\hline 1 & 95 & 75,8 & 102,8 & 84,8 & 103,6 & 80,9 & 99,2 & 83,2 & 99,5 & 73,2 \\
\hline 2 & 95,5 & 73,4 & 102,7 & 77,7 & 103,5 & 100,5 & 99,1 & 83,3 & 99,6 & 73,3 \\
\hline 3 & 95,4 & 69,1 & 102,3 & 77,6 & 103,4 & 95,5 & 99 & 83,4 & 99,7 & 73,4 \\
\hline 4 & 97 & 69,7 & 101,6 & 76,2 & 103,3 & 95,4 & 97,7 & 83,5 & 99,8 & 73,4 \\
\hline 5 & 101,7 & 70,3 & 101,5 & 76,1 & 103,2 & 83,6 & 97,6 & 83,6 & 99,9 & 73,3 \\
\hline 6 & 98 & 68,8 & 101,4 & 76 & 103,1 & 81 & 97,7 & 83,7 & 100 & 73,3 \\
\hline 7 & 94,7 & 68,9 & 101,3 & 76 & 103,2 & 79,1 & 97,8 & 83,8 & 100,1 & 76,1 \\
\hline 8 & 92,6 & 68,9 & 101,1 & 76,1 & 103,4 & 95,3 & 97,6 & 83,8 & 100 & 73,5 \\
\hline 9 & 93,3 & 70,6 & 101,2 & 76,3 & 103,3 & 84,9 & 98,8 & 83,7 & 99,9 & 73,4 \\
\hline 10 & 93,2 & 70,7 & 102,5 & 76,2 & 103,4 & 83,4 & 98,8 & 83,7 & 100,1 & 73,5 \\
\hline Rata-rata & 95,64 & 70,62 & 101,84 & 77,3 & 103,34 & 87,96 & 98,33 & 83,57 & 99,86 & 73,64 \\
\hline Koefisien & & 0,09 & & 0,08 & & 0,05 & & 0,05 & & 0,09 \\
\hline SD & & & & & 0,0205 & & & & & \\
\hline
\end{tabular}

TABEL III: Nilai taraf intensitas (TI) bunyi sebelum dan sesudah diberi busa dengan perbandingan 1:3.

\begin{tabular}{|c|c|c|c|c|c|c|c|c|c|c|}
\hline \multirow[t]{2}{*}{ No } & \multicolumn{2}{|c|}{$500 \mathrm{~Hz}$} & \multicolumn{2}{|c|}{$600 \mathrm{~Hz}$} & \multicolumn{2}{|c|}{$700 \mathrm{~Hz}$} & \multicolumn{2}{|c|}{$800 \mathrm{~Hz}$} & \multicolumn{2}{|c|}{$900 \mathrm{~Hz}$} \\
\hline & $\begin{array}{l}\text { TI Awal } \\
\text { (dB) }\end{array}$ & $\begin{array}{l}\text { TI Akhir } \\
\text { (dB) }\end{array}$ & $\begin{array}{l}\text { TI Awal } \\
\text { (dB) }\end{array}$ & $\begin{array}{l}\text { TI Akhir } \\
\text { (dB) }\end{array}$ & $\begin{array}{c}\text { TI Awal } \\
\text { (dB) }\end{array}$ & $\begin{array}{l}\text { TI Akhir } \\
\text { (dB) }\end{array}$ & $\begin{array}{l}\text { TI Awal } \\
(\mathrm{dB})\end{array}$ & $\begin{array}{l}\text { TI Akhir } \\
\text { (dB) }\end{array}$ & $\begin{array}{l}\text { TI Awal } \\
\text { (dB) }\end{array}$ & $\begin{array}{l}\text { TI Akhir } \\
\text { (dB) }\end{array}$ \\
\hline 1 & 95 & 81,8 & 102,8 & 88,8 & 103,6 & 88,8 & 99,2 & 80,8 & 99,5 & 82,5 \\
\hline 2 & 95,5 & 81,9 & 102,7 & 88,8 & 103,5 & 88,8 & 99,1 & 80,9 & 99,6 & 80,7 \\
\hline 3 & 95,4 & 81,7 & 102,3 & 88,8 & 103,4 & 88,8 & 99781 & 99,7 & 74,3 & \\
\hline 4 & 97 & 81,6 & 101,6 & 87 & 103,3 & 88,7 & 97,7 & 81 & 99,8 & 95,1 \\
\hline 5 & 101,7 & 84,6 & 101,5 & 86,9 & 103,2 & 88,6 & 97,6 & 81,2 & 99,9 & 84,6 \\
\hline 6 & 98 & 84,5 & 101,4 & 87,5 & 103,1 & 88,5 & 97,7 & 81,3 & 100 & 80,2 \\
\hline 7 & 94,7 & 84,4 & 101,3 & 87,4 & 103,2 & 88,4 & 97,8 & 81,4 & 100,1 & 78,8 \\
\hline 8 & 92,6 & 84,3 & 101,1 & 88,7 & 103,4 & 88,3 & 97,6 & 81,5 & 100 & 100,1 \\
\hline 9 & 93,3 & 84,2 & 101,2 & 88,6 & 103,3 & 88,2 & 98,8 & 81,7 & 99,9 & 95,1 \\
\hline 10 & 93,2 & 84 & 102,5 & 88,2 & 103,4 & 88,3 & $98,8781,5$ & 100,1 & 85,3 & \\
\hline Rata-rata & 95,64 & 83,3 & 101,84 & 88,07 & 103,34 & 88,54 & 98,33 & 81,23 & 99,86 & 85,67 \\
\hline $\begin{array}{l}\text { Koefisien } \\
\text { SD }\end{array}$ & & 0,04 & & $\begin{array}{c}0,04 \\
0,004\end{array}$ & & 0,04 & & 0,05 & & 0,04 \\
\hline
\end{tabular}

TABEL IV: Nilai taraf intensitas (TI) bunyi sebelum dan sesudah diberi busa dengan perbandingan 1:4.

\begin{tabular}{|c|c|c|c|c|c|c|c|c|c|c|}
\hline \multirow[t]{2}{*}{ No } & \multicolumn{2}{|c|}{$500 \mathrm{~Hz}$} & \multicolumn{2}{|c|}{$600 \mathrm{~Hz}$} & \multicolumn{2}{|c|}{$700 \mathrm{~Hz}$} & \multicolumn{2}{|c|}{$800 \mathrm{~Hz}$} & \\
\hline & $\begin{array}{l}\text { TI Awal } \\
\text { (dB) }\end{array}$ & $\begin{array}{l}\text { TI Akhir } \\
\text { (dB) }\end{array}$ & $\begin{array}{c}\text { TI Awal } \\
\text { (dB) }\end{array}$ & $\begin{array}{l}\text { TI Akhir } \\
\text { (dB) }\end{array}$ & $\begin{array}{l}\text { TI Awal } \\
\text { (dB) }\end{array}$ & $\begin{array}{l}\text { TI Akhir } \\
\text { (dB) }\end{array}$ & $\begin{array}{c}\text { TI Awal } \\
\text { (dB) }\end{array}$ & $\begin{array}{l}\text { TI Akhir } \\
(\mathrm{dB})\end{array}$ & $\begin{array}{l}\text { TI Awal } \\
\text { (dB) }\end{array}$ & $\begin{array}{l}\text { TI Akhir } \\
\text { (dB) }\end{array}$ \\
\hline 1 & 95 & 93,3 & 102,8 & 101,2 & 103,6 & 93,5 & 99,2 & 85,3 & 99,5 & 83,3 \\
\hline 2 & 95,5 & 93,4 & 102,7 & 101,1 & 103,5 & 93,5 & 99,1 & 85,5 & 99,6 & 83,5 \\
\hline 3 & 95,4 & 93,3 & 102,3 & 101,3 & 103,4 & 93,5 & 99 & 85,6 & 99,7 & 83,8 \\
\hline 4 & 97 & 93,4 & 101,6 & 98,8 & 103,3 & 93,5 & 97,7 & 85,7 & 99,8 & 84,1 \\
\hline 5 & 101,7 & 93,5 & 101,5 & 94,3 & 103,2 & 93,4 & 97,6 & 85,6 & 99,9 & 84,1 \\
\hline 6 & 98 & 93,4 & 101,4 & 94,8 & 103,1 & 93,3 & 97,7 & 85,6 & 100 & 82,1 \\
\hline 7 & 94,7 & 93,3 & 101,3 & 93,2 & 103,2 & 93,4 & 97,8 & 85,4 & 100,1 & 79,7 \\
\hline 8 & 92,6 & 93,3 & 101,1 & 100,5 & 103,4 & 93,5 & 97,6 & 85,3 & 100 & 79,6 \\
\hline 9 & 93,3 & 93,3 & 101,2 & 98, & 103,3 & 93, & 98,8 & 85,3 & 99,9 & 79,7 \\
\hline 10 & 93,2 & 92,9 & 102,5 & 98,3 & 103,4 & 93,5 & 98,8 & 85,4 & 100,1 & 79,8 \\
\hline Rata-rata & 95,64 & 93,31 & 101,84 & 98,21 & 103,34 & 93,46 & 98,33 & 85,47 & 99,86 & 81,97 \\
\hline Koefisien & & 0,01 & & 0,01 & & 0,03 & & 0,04 & & 0,05 \\
\hline SD & & & & 0,018 & & & & & & \\
\hline
\end{tabular}


TABEL V: Nilai taraf intensitas (TI) bunyi sebelum dan sesudah diberi busa dengan perbandingan 1:5.

\begin{tabular}{|c|c|c|c|c|c|c|c|c|c|c|}
\hline \multirow[t]{2}{*}{ No } & \multicolumn{2}{|c|}{$50500 \mathrm{~Hz}$} & \multicolumn{2}{|c|}{$600 \mathrm{~Hz}$} & \multicolumn{2}{|c|}{$700 \mathrm{~Hz}$} & \multicolumn{2}{|c|}{$800 \mathrm{~Hz}$} & \multicolumn{2}{|c|}{$900 \mathrm{~Hz}$} \\
\hline & $\begin{array}{l}\text { TI Awal } \\
\text { (dB) }\end{array}$ & $\begin{array}{l}\text { TI Akhir } \\
\text { (dB) }\end{array}$ & $\begin{array}{l}\text { TI Awal } \\
\text { (dB) }\end{array}$ & $\begin{array}{l}\text { TI Akhir } \\
\text { (dB) }\end{array}$ & $\begin{array}{l}\text { TI Awal } \\
\text { (dB) }\end{array}$ & $\begin{array}{l}\text { TI Akhir } \\
\text { (dB) }\end{array}$ & $\begin{array}{l}\text { TI Awal } \\
\text { (dB) }\end{array}$ & $\begin{array}{l}\text { TI Akhir } \\
\text { (dB) }\end{array}$ & $\begin{array}{c}\text { TI Awal } \\
\text { (dB) }\end{array}$ & $\begin{array}{l}\text { TI Akhir } \\
\text { (dB) }\end{array}$ \\
\hline 1 & 95 & 80,7 & 102,8 & 87,8 & 103,6 & 83,3 & 99,2 & 82 & 99,5 & 75,1 \\
\hline 2 & 95,5 & 79,4 & 102,7 & 87,9 & 103,5 & 83,5 & 99,1 & 80,4 & 99,6 & 75,1 \\
\hline 3 & 95,4 & 94,9 & 102,3 & 88 & 103,4 & 83,6 & 99 & 80,3 & 99,7 & 75,1 \\
\hline 4 & 97 & 84,6 & 101,6 & 88,1 & 103,3 & 83,7 & 97,7 & 82 & 99,8 & 75,1 \\
\hline 5 & 101,7 & 80,8 & 101,5 & 88,2 & 103,2 & 83,6 & 97,6 & 80,2 & 99,9 & 75,2 \\
\hline 6 & 98 & 80,9 & 101,4 & 88,3 & 103,1 & 83,5 & 97,7 & 80 & 100 & 75,2 \\
\hline 7 & 94,7 & 80,6 & 101,3 & 88,4 & 103,2 & 83,4 & 97,8 & 82,7 & 100,1 & 75,2 \\
\hline 8 & 92,6 & 79,9 & 101,1 & 88,3 & 103,4 & 83,4 & 97,6 & 81,1 & 100 & 75,5 \\
\hline 9 & 93,3 & 99,8 & 101,2 & 88,2 & 103,3 & 83,4 & 98,8 & 79,7 & 99,9 & 75,2 \\
\hline 10 & 93,2 & 95,2 & 102,5 & 88,2 & 103,4 & 83,3 & 98,8 & 79,7 & 100,1 & 76,9 \\
\hline Rata-rata & 95,64 & 85,68 & 101,84 & 88,14 & 103,34 & 83,47 & 98,33 & 80,81 & 99,86 & 75,36 \\
\hline Koefisien & & 0,03 & & 0,04 & & 0,06 & & 0,06 & & 0,09 \\
\hline SD & & & & 0,023 & & & & & & \\
\hline
\end{tabular}

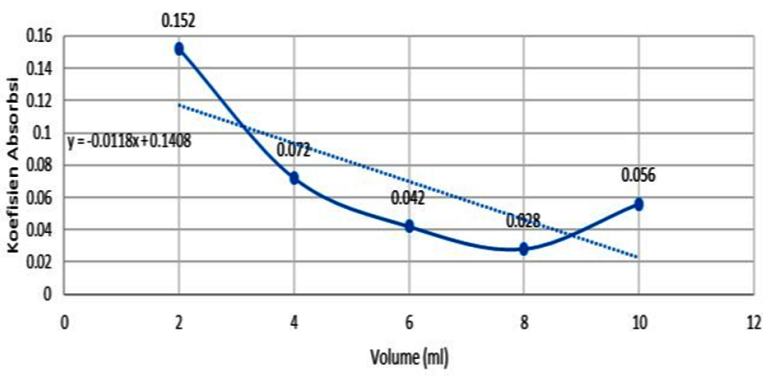

Gambar 2: Hubungan antara penambahan polyurethan terhadap koefisien absorbsi bunyi.

sar 9,96 dB. Dengan menggunakan persamaan (1) diperoleh koefisien absorbsi bunyi sebesar 0,03. Pada saat diberi sumber frekuensi 600, 700, 800 dan $900 \mathrm{~Hz}$ diperoleh selisih taraf intensitas bunyi sebelum dan sesudah masing-masing sebesar $13,66 \mathrm{~dB}, 19,87 \mathrm{~dB}, 17,52 \mathrm{~dB}$ dan 24,5 dB. Sehingga diperoleh nilai koefisien absorbsi bunyi pada frekuensi tersebut masing-masing sebesar 0,04; 0,06; 0,06; dan 0,09. Dengan demikian pada perbandingan 1:5 diperoleh rata-rata sebesar 0,056 dengan nilai standar deviasi sebesar 0,023 . Untuk gambar bahan dapat dilihat pada Gambar 2 .

\section{Diskusi/Pembahasan}

Dengan menggunakan Persamaan (1) dapat ditentukan nilai koefisien absorbsi bunyi. Nilai koefisien absorbsi bunyi berbeda untuk setiap bahan. Meskipun diberi frekuensi yang berbeda-beda, setiap bahan memiliki nilai koefisien absorbsi bunyi yang hampir sama.

Pada perbandingan bahan pengembang dan polyurethan 1:1 hingga 1:5 diperoleh nilai koefisien absorbsi bunyi berturutturut 0,$152 ; 0,072$ : 0,$042 ; 0,028$; dan 0,056. Hubungan antara nilai koefisien absorbsi bunyi dengan komposisi/ perbandingan volume bahan yang digunakan ditunjukkan pada Gambar 2 .

Dari grafik dalam Gambar 2 diketahui bahwa jika komposisi polyurethan semakin besar maka nilai koefisien absorbsi bunyi semakin kecil. Hal ini ditunjukkan pada grafik dari bahan 1:1 sampai 1:4, nilai koefisien absorbs bunyi terus berkurang. Penurunan nilai ini dapat disebabkan karena tekstur bahan yang semakin lembut dan rongga yang berkurang dari 1:1 hingga 1:4.

Pada komposisi bahan 1:5 nilai koefisien absorbsi bunyi bertambah. Ada kemungkinan terjadi penambahan nilai koefisien absorbs bunyi jika perbandingan polyuretan diperbesar. Namun tekstur pada saat 1:5 menunjukkan terjadi penyusutan ukuran sampel dan bentuk sampel menjadi tidak beraturan. Ukuran diameter sampel menjadi semakin kecil sedangkan ketebalan meningkat seiring ketidakberaturan bentuk sampel. Selain itu, tekstur bahan juga lebih padat dan terlihat lebih banyak rongga.

\section{SIMPULAN}

Berdasarkan hasil analisis data, ditemukan bahwa semakin banyak komposisi bahan polyurethan maka semakin kecil koefisien absorbsi bunyi begitu pula sebaliknya. Koefisien absorbsi bunyi yang terbesar diperoleh adalah 0,152 pada perbandingan 1:1. Berdasarkan nilai koefisien absorbsi bunyi pada penelitian yang dihasilkan ini, diketahui komposisi bahan 1:1 memiliki daya serap bunyi yang paling tinggi dibandingkan dengan perbandingan bahan lain. Dengan kata lain sampel bahan 1:1 (mengurangi poliurethan) dapat meningkatkan kemampuan meredam suara busa home made foam.

\section{Ucapan Terima Kasih}

Penelitian ini didukung oleh Program Pascasarjana Universitas Negeri Yogyakarta dan Laboratorium Fisika MIPA Universitas Negeri Yogyakarta. 
[1] R.J. Sitorus, and I.G. Purba, "Health Risk Assessment of Work Factors Physical and Chemical Factors in the Center of Collecting Production (Ppp) Pt.pertamina Ep. Region Field Sumatera Prabumulih", Jurnal Ilmu Kesehatan Masyarakat, vol. 2, no. 3, hlm. 167-172, 2015. [https:// media.neliti.com/media/publications /57888-ID-health-riskassessment-of-work-factors-p.pdf]

[2] T. Mulia, and A.R.Z. Amin, "Kaitan Material Dan Kualitas Akustik Pada Ruang Audio Visual Universitas Katolik Musi Charitas Palembang (Ecotect Analysis)", Jurnal Arsitektur KOMPOSISI, vol. 11, no. 3, hlm. 127-138, 2017. [http://ojs.uajy.ac.id/index.php/komposisi/article/ viewFile/1186/993].

[3] W. Siregar, T. Emrinaldi, dan W. Tambunan, "Penentuan Koefisien Absorpsi Gelombang Bunyi Dari Kertas Kardus, 2013. [https://repository.unri.ac.id/xmlui/bitstream/handle/123456789/ 2443/Karya\%20Ilmiah\%20Wahyuddin\%20Siregar\%2007 $\% 2001 \% 202013$.pdf?sequence=1]

[4] S. Febrian, "Pengaruh Pemakaian Multi Layer Material Pada Casing Peredam Suara Mesin Diesel", Prosiding Seminar Hasil Penelitian Universitas Darma Persada, 2014 [http://onesearch.id/Record/IOS5096.142]

[5] A. Katherina, dan E. Sutrisno, "Perancangan Pengendalian Bising dengan Pemasangan Rock Wool pada Ruang Pegawai di Dipo Lokomotif Semarang Poncol”, Jurnal Teknik Lingkungan, vol. 5, no. 2, hlm 1-14, 2016. [https:// ejournal3. undip.ac.id/index.php/tlingkungan/article/download/11747/11402]

[6] A. Khuriati, dan E. Komaruddin, "Disain peredam suara berbahan dasar sabut kelapa dan pengukuran koefisien penyerapan bunyinya", Berkala Fisika, vol. 9, no. 1, hlm. 15-25, 2006. [https://ejournal.undip.ac.id/index.php/berkalafisika/article/download/3107/2788]

[7] D.M. Sinaga, "Pengukuran Koefisien Absorpsi Bunyi dari Limbah Batang Kelapa Sawit", Komunikasi Fisika Indonesia, vol. 9, no. 5, hlm. 415-423, 2013. [https:// ejournal.unri.ac.id/index.php/JKFI/article/download/ 1201/1192]

[8] W. Hayat, "Pengaruh Kerapatan Terhadap Koefisien Absorbsi Bunyi Papan Partikel Serat Daun Nenas (AnanascomosusL Merr)", PILLAR OF PHYSICS, vol. 1, no. 1, )2013, p. 44-51, 2013. [http:// ejournal.unp.ac.id/students/index.php/fis/article/download/ 501/290]

[9] G. Sung, J.S. Kim, and J.H. Kim, "Sound absorption behavior of flexible polyurethane foams including high molecular?weight copolymer polyol", Polymers for Advanced Technologies, vol. 29, no. 2, pp.852-859, 2018. [https://doi.org/10.1002/pat.4195]

[10] J.G. Gwon, S.K. Kim, and J.H. Kim, "Sound absorption behavior of flexible polyurethane foams with distinct cellular structures. Materials adn Design", vol. 89, pp. 448-454, 2016. [https://doi.org/10.1016/j.matdes.2015.10.017.] 